\title{
Proteomic Analysis of a Compatible Interaction between Sorghum Downy Mildew Pathogen (Peronosclerospora sorghi) and Maize (Zea mays L.)
}

\author{
K.P. Jadhav ${ }^{1 *}$, R. Veera Ranjani ${ }^{1}$, N. Senthil ${ }^{2}$, N. Arulkumar ${ }^{3}$, P.M. Tamilarasi ${ }^{5}$,
} K. Sumathi ${ }^{5}$, K.N. Ganesan ${ }^{5}$, V. Paranidharan ${ }^{4}$, M. Raveendran ${ }^{1}$, Gon Sup Kim ${ }^{3}$ and J. Ramalingam ${ }^{1}$

${ }^{1}$ Centre for Plant Molecular Biology and Biotechnology, Tamil Nadu Agricultural University, Coimbatore - 641 003, Tamil Nadu, India

${ }^{2}$ Department of Biotechnology, Agriculture College \& Research Institute, Tamil Nadu

Agricultural University, Madurai - 625 104, Tamil Nadu, India

${ }^{3}$ Research Institute of Life Science and College of Veterinary Medicine Gyeongsang National

University Jinju, Gyeongnam - 660 701, South Korea

${ }^{4}$ Department of Plant Pathology, Centre for Plant Protection Studies, Tamil Nadu

Agricultural University, Coimbatore - 641 003, Tamil Nadu, India

${ }^{5}$ Centre for Plant Breeding and Genetics, Tamil Nadu Agricultural University,

Coimbatore - 641 003, Tamil Nadu, India

*Corresponding author

\section{A B S T R A C T}

\section{Keywords}

Maize, Sorghum downy mildew, 2D-PAGE,

MALDI-TOF,

Lipoxygenase, Cell cycle

\section{Article Info}

Accepted:

07 October 2018

Available Online:

10 November 2018
Sorghum downy mildew (SDM) caused by the oomycete, Peronosclerospora sorghi, is one of the destructive diseases that afflict maize. P. sorghi infects a susceptible host, hindering its growth and altering its morphology. To understand the molecular basis of the compatibility interaction between $P$. sorghi and maize, a comparative proteomic approach (2D-PAGE) was employed between the mock-inoculated (control) and SDM-inoculated leaves in the susceptible genotypes of maize (UMI79 and CM500). Seventeen spots showed a significant difference in the abundance of proteins in control and inoculated samples were further analyzed with MALDI-TOF/MS. The resulting peptide mass fingerprint was subjected to MASCOT analysis and it was found that most were related to stress that includes lipoxygenase and DEAD-box ATP-dependent RNA helicases, microtubule-associated protein and probable protein disulphide isomerase. Additionally, proteins involved in the cell cycle/endoreplication such as DNA topoisomerase 6 subunit $\mathrm{A}$ and retinoblastoma-related proteins were differentially expressed during infection. The possible roles of these proteins in response to $P$. sorghi infection in maize are discussed.

\section{Introduction}

Maize is the third most important crop worldwide after rice and wheat (Hoisington and Melchinger 2004). It is affected by several pests and diseases. Among the diseases, sorghum downy mildew (SDM), caused by Peronosclerospora sorghi [(Weston and 
Uppal) C. G. Shaw], an obligate oomycete, is one of the destructive diseases. Downy mildew has had a cosmopolitan distribution from 1960 in all maize growing areas of Indonesia, the Philippines, Thailand, Nepal, and India (Gerpacio and Pingali, 2007). In India, SDM is predominant in the southern states (Karnataka, Tamil Nadu and Andhra Pradesh), causing yield losses of $30 \%$ and higher (Yen et al., 2004).

The SDM pathogen, $P$. sorghi, infects maize through oospores (sexual phase) and/or conidia (asexual phase). The primary inoculum, the oospore, enters through the roots and causes systemic infection, whereas the conidia act as the secondary source of inoculum. Conidia enter through leaf lamina at the onset of conducive weather conditions and cause local infection. It may also lead to systemic infection, if seedlings less than a week old are affected.

SDM infection leads to the development of characteristic symptoms, including the halfleaf stage in which half of the leaf lamina from the base becomes chlorotic and extends further at later stages of infection and finally covers the whole lamina (Safeeulla, 1976; Williams, 1984). The infected leaf becomes narrow and erect. The tassel is replaced by a vegetative structure called 'crazy top' and pollen production is hampered. SDM infection at early developmental stages leads to shortening of the internode and a stunted appearance of the plant (Ajala et al., 2003; Williams, 1984). Thus, SDM infection alters the growth and morphology of maize during compatible interaction. These alterations may likely be accounted for by the changes in plant proteome level. With the aid of proteomics, identifying and quantifying the proteins involved in plant - pathogen interaction has become easier, which may help to elucidate their relative importance in the process of disease development (Amey et al., 2008). 2D-
PAGE and mass spectroscopy are powerful proteomic tools that have gained importance in plant pathology to characterize proteins from either the phytopathogen or the host plant or both (Kav et al., 2007).

Understanding plant disease resistance mechanisms has been emphasized over the decades and numerous studies have been devoted to examine the differential expression of proteins involved in an incompatible interaction, i.e., to evaluate resistant genotype response, but there are few reports on compatible interaction. However, studies on compatible interaction will ultimately help us to improve our understanding regarding plant disease susceptibility. The few proteomics studies that focused on compatible phyto pathogen interaction includes Pisum sativumPeronospora viciae (Amey et al., 2008), Triticum aestivum-Fusarium graminearum (Zhou et al., 2006), Vitis vinifera-Plasmopara viticola (Milli et al., 2012), Vigna mungoMungbean Yellow Mosaic virus (Cayalvizhi et al., 2015; Kundu et al., 2013), Fagus sylvatica-Phytophthora citricola (Valcu et al., 2009), and Zea Mays L. - Rice Black-Streaked Dwarf Virus (Li et al., 2011).

An obligate biotrophic pathogen infects susceptible plants, establishes itself in the plant structures and makes it compatible to harvest nutrients without killing the host plant. Thus, understanding the molecular mechanism of compatible interaction would help elucidate novel protection strategies by interfering with the compatibility (Hok et al., 2010).

Hence, a 2D-PAGE strategy was employed to understand differential protein abundance in control and SDM-inoculated samples of two susceptible genotypes of maize (UMI79 and CM500) and their relative importance in disease susceptibility, possible involvement in morphological and developmental changes in the host. 


\section{Materials and Methods}

\section{Plant materials}

Two test genotypes were used in this study: UMI79 (origin - Pioneer 102), an elite welladapted superior maize inbred, but it is susceptible to SDM infection; and CM500 (origin - Antigua Gr 1), an open pollinated variety that is a national check and spreader for all types of downy mildew studies. Though both genotypes are highly susceptible to SDM, the levels of susceptibility are different.

One study (Nallathambi et al., 2010) reported that UMI79 was affected by SDM with $68 \%$ disease incidence and CM500 with 100\% disease incidence. Another group in 2010 also reported that maximum disease incidence among 100 maize inbreds was registered in CM500 (Premalatha et al., 2012).

Inoculation of maize seedling with a conidial suspension of $P$. sorghi

Seeds of SDM-susceptible genotypes (UMI79 and CM500) were sown in pots in a glasshouse at a controlled temperature $\left(20^{\circ} \mathrm{C}\right)$ and humidity (>90). Nine days after sowing, SDM-infected maize leaves showing visible conidial growth were collected from infected fields in the evening. Leaves were wiped with cotton to remove mature conidiophores, and then placed overnight for sporulation in moist gunny bags under controlled temperature (20$22^{\circ} \mathrm{C}$ ) and humidity $(>90 \%)$.

The next morning, at around 3.00 AM, fresh conidia were harvested from leaves in chilled water using a brush, and diluted to the desired $6 \times 10^{5}$ conidia per $\mathrm{mL}$ concentration. The resulting conidial suspension of $P$. sorghi was sprayed over ten-day-old seedlings using the "seedling spray inoculation" technique (Craig et al., 1977), whereas the control was mock inoculated with sterile distilled water.

\section{Phenotypic observation of SDM}

The inoculated plants were observed for the occurrence of morphological and phenotypic changes due to SDM. As the reduction in total chlorophyll content is a common characteristic of plant fungal disease, the total chlorophyll content was recorded using a portable chlorophyll meter (Minolta SPAD-502 Plus; Konica Minolta Inc., Europe) at 20 dpi. Leaf narrowing is another symptom of SDM, so width of the mock/SDM inoculated leaves was measured and compared.

To understand the level of susceptibility in two susceptible genotypes, at $20 \mathrm{dpi}$, the leaf samples inoculated with SDM (20 dpi) were cut into $5 \mathrm{~mm}^{2}$ pieces, and both the adaxial and abaxial surfaces were mounted on stubs and observed under an ICON-Quanta 200 Mark II Environmental Scanning Electron Microscope (ESEM) in low vacuum mode.

\section{Sample collection and protein extraction}

Three biological replicates of leaf tissue were collected at 20 dpi from each control and SDM-inoculated plant and stored in liquid nitrogen at $-80^{\circ} \mathrm{C}$ until protein extraction. Frozen leaf tissues were finely powdered with liquid nitrogen in a pre-chilled mortar and pestle, suspended in $10 \mathrm{~mL}$ trichloro acetic acid (TCA) extraction buffer $(10 \%(\mathrm{w} / \mathrm{v})$ TCA in $10 \%(\mathrm{v} / \mathrm{v})$ in acetone and $0.07 \%(\mathrm{w} / \mathrm{v})$ dithiothreitol (DTT)), then the samples were incubated at $-20^{\circ} \mathrm{C}$ for $1 \mathrm{~h}$. Following incubation, the extract was centrifuged at $12,000 \mathrm{rpm}$ for $20 \mathrm{~min}$. The supernatant was discarded and the pellet was washed with icecold acetone containing (w/v) $0.07 \%$ DTT. Washing was repeated until the pellet was devoid of chlorophyll. Finally, the pellet was lyophilized for $2 \mathrm{~h}$ and stored at $-80^{\circ} \mathrm{C}$. About $15 \mathrm{mg}$ of lyophilized powder was resuspended in $200 \mu \mathrm{L}$ of lysis buffer (9M urea, $4 \%(w / v)$ CHAPS, $1 \%(w / v)$ DTT, $1 \%(w / v)$ 
ampholyte (pH 3-10), $35 \mathrm{mM}$ Tris base) The samples were incubated at $37{ }^{\circ} \mathrm{C}$ for $1 \mathrm{~h}$ with intermittent vortexing followed by centrifugation. The supernatant served as the protein extract and the concentration of protein was determined using the Bradford method (Bradford 1976).

\section{Two-dimensional electrophoresis (2-DE)}

For the first dimension, $150 \mu \mathrm{g}$ of proteins was rehydrated using $17 \mathrm{~cm}$ immobilized linear $\mathrm{pH}$ gradient (IPG) strips (Bio-Rad laboratories, USA), $\mathrm{pH} 4-7$, in a rehydration buffer (8M urea, $2 \%(\mathrm{w} / \mathrm{v})$ CHAPS, $0.07 \%(\mathrm{w} / \mathrm{v})$ DTT and $50 \mu \mathrm{L}$ of IPG buffer). Isoelectric focusing was performed at $20^{\circ} \mathrm{C}$ with a GE Healthcare Life-sciences Multiphor II kit. Electrophoresis was carried out at $500 \mathrm{~V}$ for $30 \mathrm{~min}, 1000 \mathrm{~V}$ for $30 \mathrm{~min}$ and $3000 \mathrm{~V}$ for $10 \mathrm{~h}$. Prior to the second dimension, the IPG strips were equilibrated twice for $15 \mathrm{~min}$ each in 20 $\mathrm{mL} / \mathrm{strip}$ of equilibration solution containing 6 $\mathrm{M}$ urea, 30\% (v/v) glycerol, 2.5\% (w/v) SDS, and $50 \mathrm{mM}$ Tris-HCL. DTT $(50 \mathrm{mM})$ was added to the first equilibration solution and $4 \%(\mathrm{w} / \mathrm{v})$ iodoacetamide was added to the second. For the second dimension, equilibrated IPG strips were placed on top of vertical sodium dodecyl sulphatepolyacrylamide gels (12\%) (Jagadish et al., 2010). Electrophoresis was performed at $4^{\circ} \mathrm{C}$ in a $1 \times$ SDS buffer at $30 \mathrm{~mA} /$ gel constant current. 2-DE gels were stained with silver nitrate (Blum et al., 1987). 2-DE silver-stained gels were scanned for image visualization and for densitometrical analysis by using the ImageMaster 2D Platinum version 7, Scanner III (GE Healthcare, USA). Total number of spots, matched spots and differential expressed spots were counted separately to each replication and analysis of variance was done to find any significant difference. The abundance ratio (AR) of spots was calculated by the percentage of volume of spot under inoculation to the ratio of the percentage of volume of spot under control. The criterion for differential expression of protein was based on the AR: when AR > 1, then the spot is said to be upregulated, when AR $<1$ then the spot is said to be downregulated (Jagadish et al., 2010).

\section{Peptide mass fingerprinting (PMF)}

Protein spots of different intensities and regions of the 2-DE gel were selected for PMF analysis. Samples were excised manually using a scalpel from a silver-stained 2-DE gel, dehydrated in $100 \%$ acetonitrile (ACN), dried by vacuum centrifugation, and subjected to trypsin digestion overnight at $37^{\circ} \mathrm{C}$. Samples were dehydrated and mixed with an equal volume of matrix solution ( $\alpha$-acyano- 4hydroxycinnamic acid, HCCA) and then subjected to MALDI TOF/MS (Shevchenko et al., 1996) (matrix-assisted laser desorption/ionization time-of-flight/mass spectroscopy) on a Voyager-DE STR mass spectrometer (Applied Biosystems, Franklin Lakes, NJ, USA).

\section{Identification of putative proteins by MASCOT analysis}

Proteins were identified by correlative searching PMF against well-curated swissprot databases in Oryza sativa L. taxonomy, using the MASCOT program (http://www. matrixscience.com) (Cottrell and London 1999). The following parameters were applied during the MASCOT search: peptide fragment tolerance of $100 \mathrm{ppm}$, maximum number of missed trypsin cleavages one, carbamidomethylation of cysteine as fixed modification and oxidation of methionine as variable modification were allowed. Decoy search was done automatically by Mascot on randomized database of equal composition and size. The peptide mixtures that produced the highest statistically significant $(\mathrm{P}<0.05)$ match scores and accounted for the majority 
of the peaks present in the mass spectra, were considered to be positively identified proteins. The identified proteins were categorized based on their probable biological function and discussed.

\section{Results and Discussion}

\section{Phenotypic observation of SDM symptoms} in the control and SDM-inoculated leaves

At $20 \mathrm{dpi}$, it was observed that the mockinoculated controls of both genotypes were symptomless, whereas the SDM-inoculated leaves showed typical symptoms of chlorosis, downy growth and narrowing of leaves (Fig. 1). Depletion of chlorophyll was observed in the SDM-inoculated leaves over the control. Most of the SDM-inoculated leaves of the UMI79 genotype showed the half leaf-stage symptom, whereas at the same timeframe (20 dpi), the CM500 inoculated leaves showed full leaf chlorosis. The mean decrease in chlorophyll content was $53 \%$ for UMI79 and $61 \%$ for CM500 over its respective control (Table 1). SDM infection also led to narrowing of the leaves. Leaf width decreased by 23 and $30 \%$ over control in UMI79 and CM500, respectively. The downy growth was evident on the adaxial and abaxial surfaces of the leaf.

\section{SDM-inoculated leaf sample analysis with ESEM}

ESEM was adapted to analyze the abaxial and adaxial surfaces of SDM-inoculated leaf samples at $20 \mathrm{dpi}$. The conidiophore was consistently observed to be exiting through the stomata from both surfaces of the leaf. The progression of the emergence of conidiophore was found to be slower in the UMI79 genotype than CM500 (Fig. 2). At 20 dpi, the unbranched conidiophores found emerging from the stomata was observed in the UMI79 genotype, while at the same timeframe, matured conidiophores bearing conidia were observed on both surfaces of CM500. CM500 had a greater amount of conidiophores on the leaf surface. Moreover, two or more conidiophores emerging from single stomata was often seen in CM500.

\section{Effect of SDM on host protein expression}

Proteomics is a powerful tool for studying plant response to different stress factors, including plant - pathogen interactions, plant herbivore interactions and wounding (Butt and Lo 2007). Of the methods employed in recent proteomics studies, 2-DE provides reasonably good resolution and coverage of the proteome. 2-DE gel analysis was executed for the control and SDM-inoculated samples. ImageMaster 2D Platinum version 7 software detected an average of $1066 \pm 37$ and $1211 \pm 22$ spots in silver stained gels of control and inoculated samples of UMI79. Whereas, $676 \pm 3$ and 915 \pm 26 spots were evident in the gels of control and inoculated samples of CM500. Approximately 330 spots were matched among all the gels. Four upregulated, nine downregulated and two newly induced proteins spots after infection in both genotypes along with the one newly induced spot and one downregulated spot exclusively in the UMI79 were chosen for analysis (Fig. 3).

Figure 4 represents the seventeen protein spots that showed variation in expression after infection. Of these 17 protein spots, the abundance of ten proteins was low (depicted as D1-D10), four were high (depicted as U1U4) and three protein spots were present only in the $P$. sorghi inoculated samples (depicted as N1-N3). Thus, the 17 spots used for trypsin digestion and subjected to MALDI TOF/MS, and further identified and characterized using the MASCOT program, are shown in Table 2. Of these 17 protein spots, the protein spots corresponding to D1 and D2 were found to be phosphatase and pentatricopeptide repeat- 
containing protein OTP51, respectively. D3, D4 and N3 were acyl-[acyl-carrier-protein] desaturase with different isoforms. D5 and D6 were found to be DNA topoisomerase 6 subunit $\mathrm{A}$ and microtubule-associated protein, respectively. DEAD-box ATP-dependent RNA helicase was represented by more than one protein spot. The protein spots D7, D9 and U3 corresponded to DEAD-box ATPdependent RNA helicase 50, 52B and 16, respectively. D8 and N2 were found to be lipoxygenase 7 and probable linoleate $9 \mathrm{~S}$ lipoxygenase 4 , respectively. The PMF of spots corresponding to D10 and U2 did not match any protein in the MASCOT analysis.

Further, biological annotation was done for the proteins, which were classified into six categories based on their putative functions in the UniProtKB database (http://www.uniprot.org/) and previous literature (Table 2). The categories include signal transduction, organeller gene expression, stress/defense, fatty acid metabolism, cell cycle/endoreplication, and energy. The probable role of each protein in compatible interaction is discussed with hypothetical network (Fig. 5).

The downy mildew of maize remains an important constraint in establishing sustainable crop production worldwide. Severe yield losses have been reported during the twentieth century from warm and moist tropical and subtropical areas (Singburaudom and Renfro 1982). Metalaxyl is an effective fungicide for all downy mildews, but Metalaxyl resistance developed by some of the downy mildew pathogens, including $P$. parasitica and $P$. sorghi, has limited its widespread use (Isakeit et al., 2003). Hence, it is necessary to find an alternative strategy to control downy mildew. Studying molecular events associated with compatible phytopathogen interaction at the proteomic level will provide a way to elucidate the molecular mechanism of disease establishment and symptom development, and thus to develop novel control strategies.

This study was conducted to help understand host proteins altered in abundance after infection in both the genotypes during maize $P$. sorghi interaction. Fifteen overlapping proteins spots between UMI79 and CM500 and two UMI79 genotype-specific protein spots that are differentially expressed after infection were subjected to PMF and MASCOT analysis. Further, the probable functions of the proteins were identified (Table 2) and their probable role in compatible plant - pathogen interaction is discussed according to their functional categories.

\section{Signal transduction}

Protein kinases and phosphatases are key signal transducers during plant - pathogen interaction that leads to plant defense responses (Xing et al., 2002). Probable protein phosphatase 2C 77 (PP2C) was found to be downregulated (D1) in both the genotypes after infection, but the extent of downregulation was higher in the CM500 genotype $(\mathrm{AR}=0.11 \pm 0.03)$ than UMI79 $(\mathrm{AR}=0.28 \pm 0.06)$. The protein phosphatase is involved in numerous cellular processes like plant growth, development, abscisic acid (ABA) signaling and response to environmental stresses.

Upregulation of $\mathrm{PP} 2 \mathrm{C}$ has been reported previously in incompatible MYMV-Vigna mungo interaction (Kundu et al., 2013), and it was thought to be involved in pathogen effector recognition and the induction of the resistance response by triggering $\mathrm{PR}$ protein production in the resistant genotype. Transgenic tobacco was successfully produced against tobacco virus with overexpression of the rice $\mathrm{PP} 2 \mathrm{C} 2$ gene that improved disease resistance (Hu et al., 2009). 
$\mathrm{PP} 2 \mathrm{C}$ is a negative regulator of ABA signaling pathways (Schweighofer et al., 2004; Sheen 1998). ABA is widely known for its role in abiotic stress but it also plays a significant role in biotic stress. In the initial stage of pathogen infection, ABA induces stomata closure and callose deposition thereby restricting pathogen entry.

However, after successful entry and establishment of the pathogen (later stage of the infection) in the susceptible plant, it negatively regulates disease resistance at the later stage of infection by suppressing ROS production, which was evident in tomato and Botrytis cinerea interaction (Asselbergh et al., 2007), and also negatively regulates the salicylic acid pathway thus hampering systemic acquired resistance (SAR) (Mohr and Cahill 2007; Yasuda et al., 2008). In this present compatible interaction study $(P$. sorghi-maize), ABA might have induced upon the downregulation of $\mathrm{PP} 2 \mathrm{C}$, which thereby suppressed the SAR response and helped in the colonization of the pathogen.

\section{Regulation of organelle gene expression}

Pentatricopeptide repeat-containing protein (OTP51) regulates organeller gene expression through post-transcriptional control such as intron splicing, RNA editing, RNA processing, RNA stability and RNA cleavage (Schmitz-Linneweber and Small 2008). In chloroplasts, it is also involved in photosystem I assembly. The loss of this OTP51 deleteriously affects photosystem I and II of the Arabidopsis thaliana mutant (Longevialle et al., 2008). In the present study, pentatricopeptide repeat-containing protein OTP51 (spot D2) was found to be downregulated in the SDM-inoculated samples of both the susceptible genotypes of the maize. The downregulation was higher in the CM500 $(\mathrm{AR}=0.22 \pm 0.03)$ than the UMI79 genotype $(\mathrm{AR}=0.57 \pm 0.09)$. Similarly, depletion of chlorophyll content measured by SPAD was higher in CM500 than UMI79. Thus, both proteomics and SPAD reading suggest that the pathogen affected the photosynthesis process and its effect was high on the CM500.

\section{Stress/defense}

The DEAD-box RNA helicases comprise the largest subfamily of RNA helicases. DEADbox RNA helicases are prominent candidates for RNA chaperones because these proteins can use energy derived from nucleotide triphosphate hydrolysis to actively disrupt misfolded RNA structures so that correct folding can occur. Both upregulation (U3) and downregulation (D7, D9) of DEAD-box RNA helicase was noticed after infection. Different isoforms like 50, 52B (upregulated) and 16 (downregulated) may eventually play different roles during pathogen infection. A similar phenomenon of opposite expression for some of the proteins was observed in Sugarcane mosaic virus and maize interaction indicating complex regulatory mechanisms of plants in response to pathogen infections.

The upregulation of DEAD-box ATPdependent RNA helicase 16 was much higher in the CM500 than the UMI79 (variance of $\mathrm{AR}=15.38$ thus speculating the CM500 is being undergone higher stress condition which requires higher amount of RNA chaperone specifically DEAD-box ATP-dependent RNA helicase 16 to deal with the stress condition.

The plant cytoskeleton is a highly dynamic scaffold comprising microtubules (polymer of $\alpha / \beta$ tubulin heterodimer) and microfilaments (polymer of actin monomer). It is versatile in its function and plays a role in growth and development, cell division, cell expansion, intracellular organization and organelle motility (Wasteneys and Galway 2003). 
Fig.1 Phenotypic symptoms of SDM in the control and inoculated samples of the UMI79 and CM500 genotypes. SDM symptoms such as chlorosis, leaf narrowing and white growth on the leaf surface was observed in the SDM-inoculated leaves at 20 dpi. (A) UMI79 leaf: left, control; right, SDM inoculated and (B) CM500 leaf: left, control; right, SDM inoculated

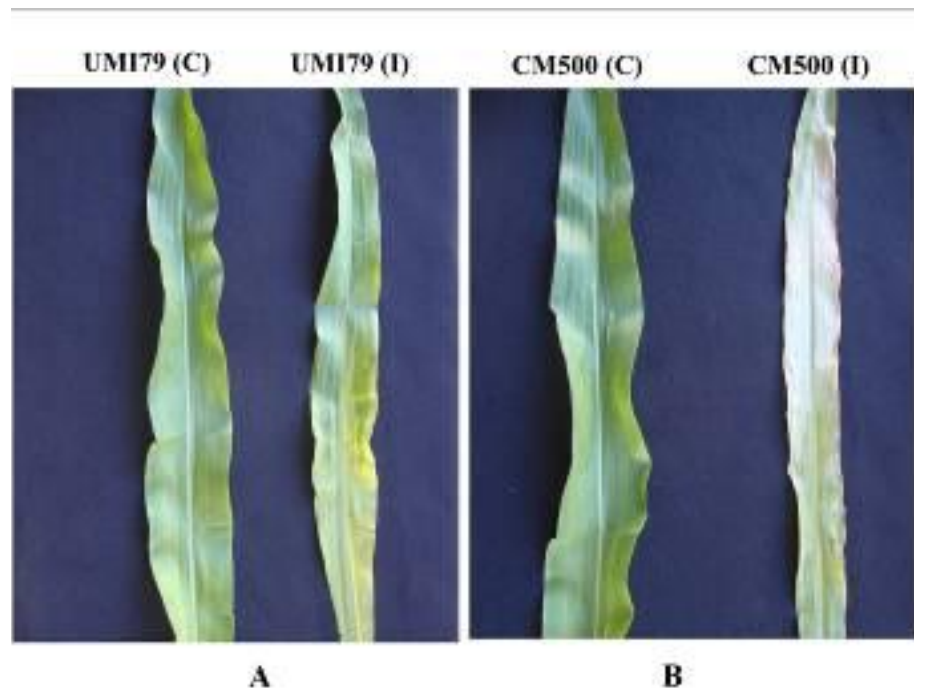

Fig.2 Environmental scanning electron microscope images of the adaxial and abaxial surfaces of SDM-inoculated leaves at $20 \mathrm{dpi}$ in the two susceptible genotypes of the maize. An unbranched conidiophore $(\mathrm{Cph})$ emerging from stomata $(\mathrm{S})$ was observed from the adaxial and abaxial leaf surfaces of the genotype UMI79. In CM500, branched and profused growth of conidiophores on the adaxial surface bearing conidia (C) on the highly susceptible genotype CM500 and two conidiophore emerging from single stomata on the abaxial surface were observed

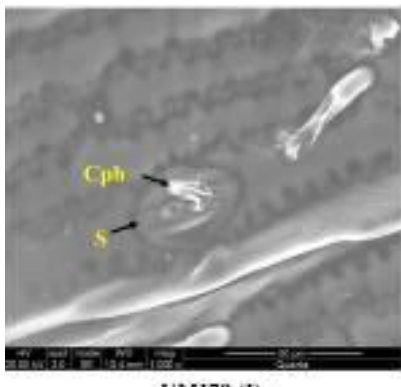

UM179 (I)
Adasial

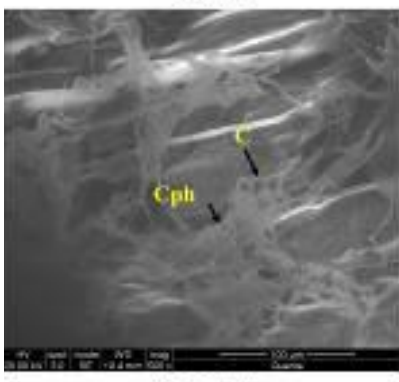

CM500 (I) Adaxial

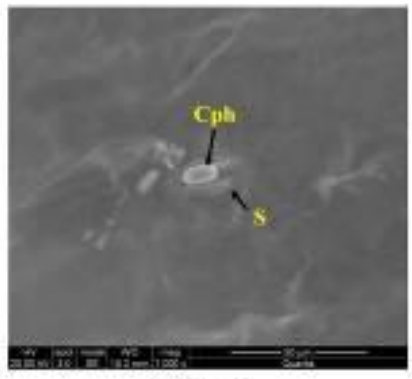

UMI79 (I)

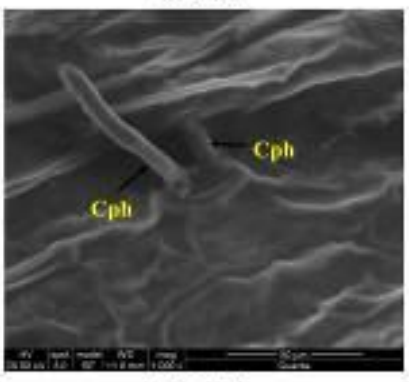

CM500 (1)

Abaxial 
Fig.3 Representative images of two-dimensional gel electrophoresis of leaf proteins from the control and SDM-inoculated susceptible maize genotype UMI79 and CM500. Downregulated protein spots were numbered D1-D10, upregulated protein spots as U1-U4, newly induced spots as N1-N3
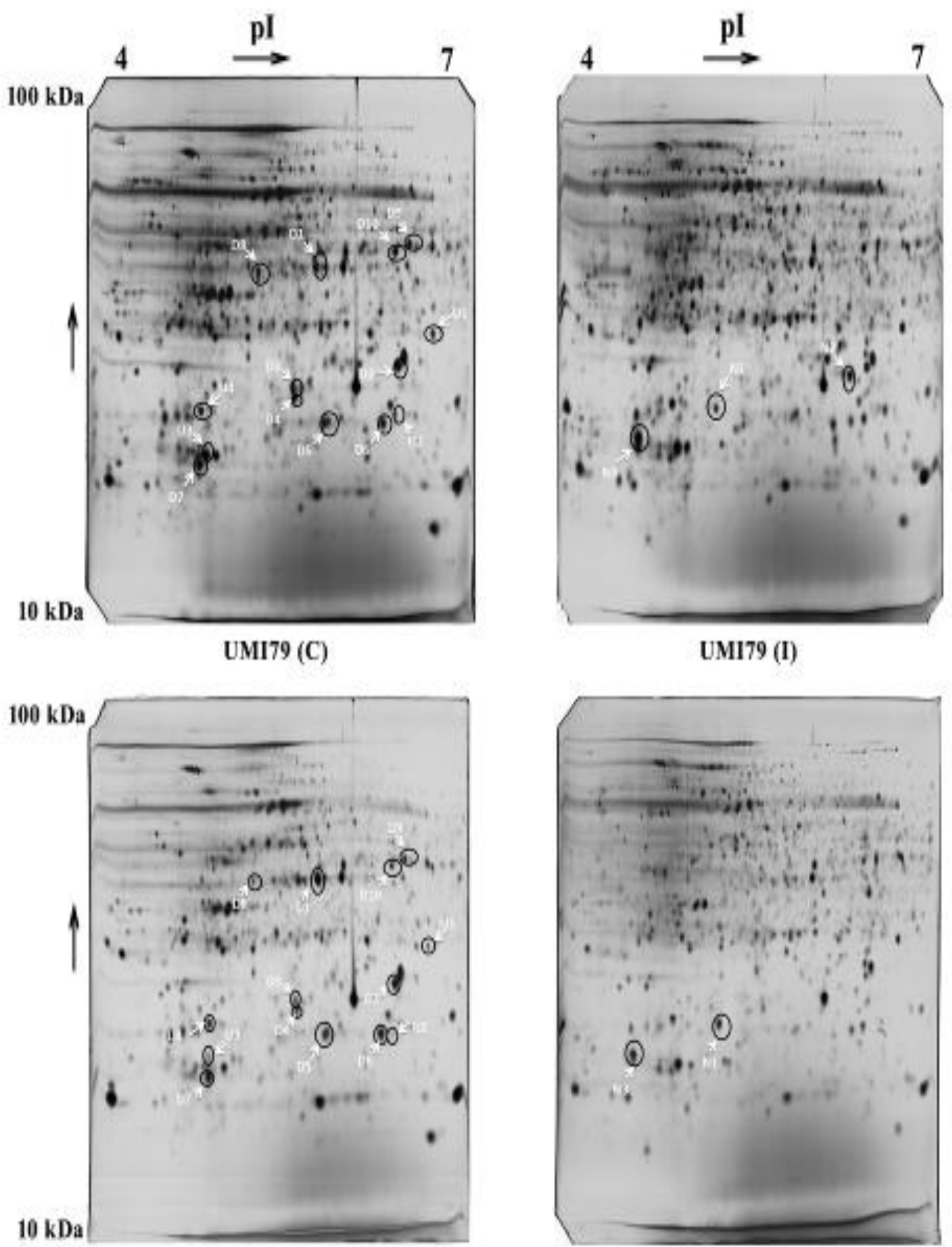

CM500 (C)

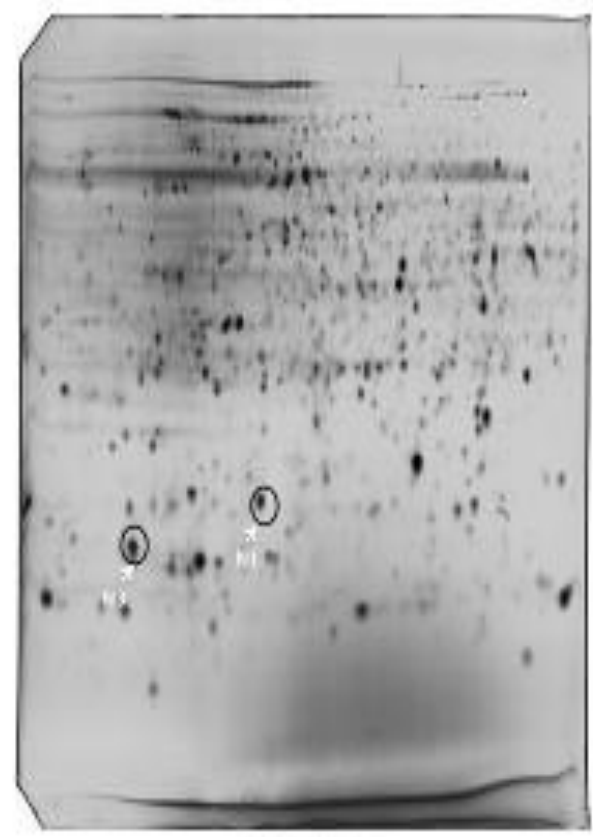

CM500 (I) 
Fig.4 Magnified view of differentially expressed proteins in two-dimensional gel in the compatible interaction between $P$. sorghi and the two maize genotypes (UMI79 and CM500). Labeled spots show significant changes in the control and SDM-inoculated samples. (I) denotes inoculated samples; (C) denotes control samples
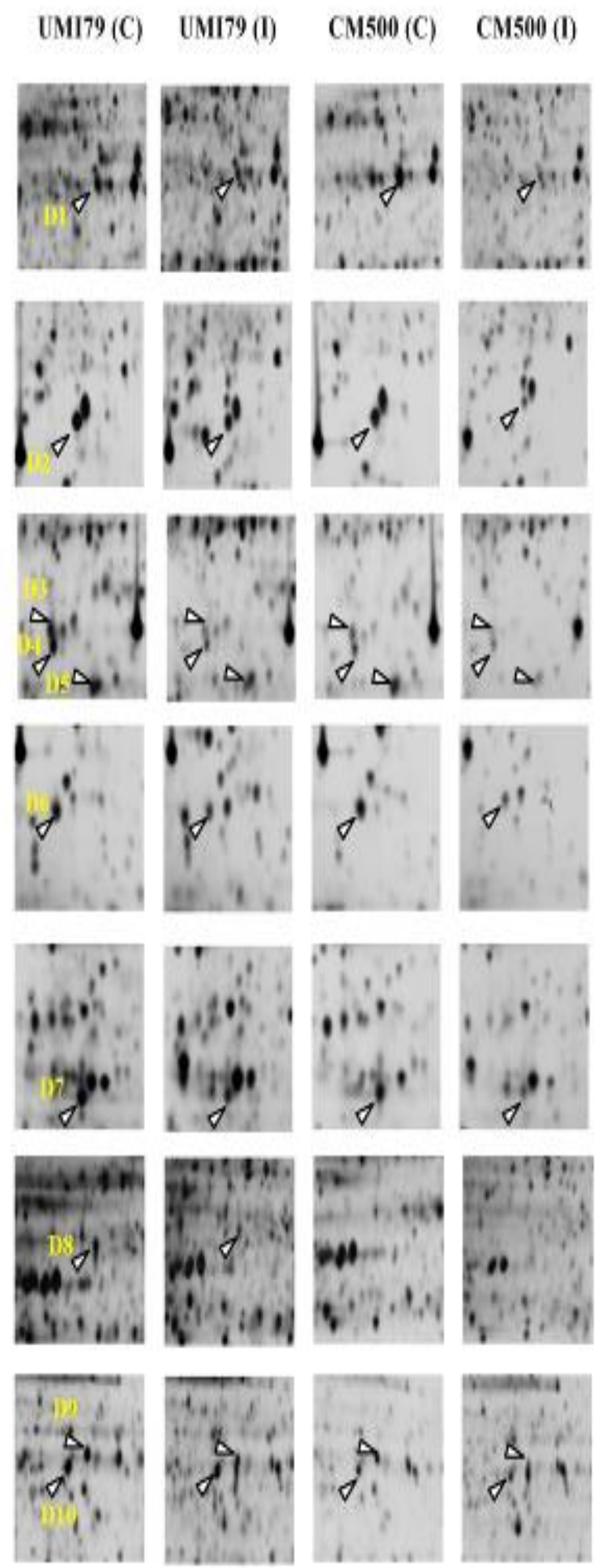

\section{UMI79 (C) \\ UMI79 (I)}

CM500 (C)

CM500 (I)
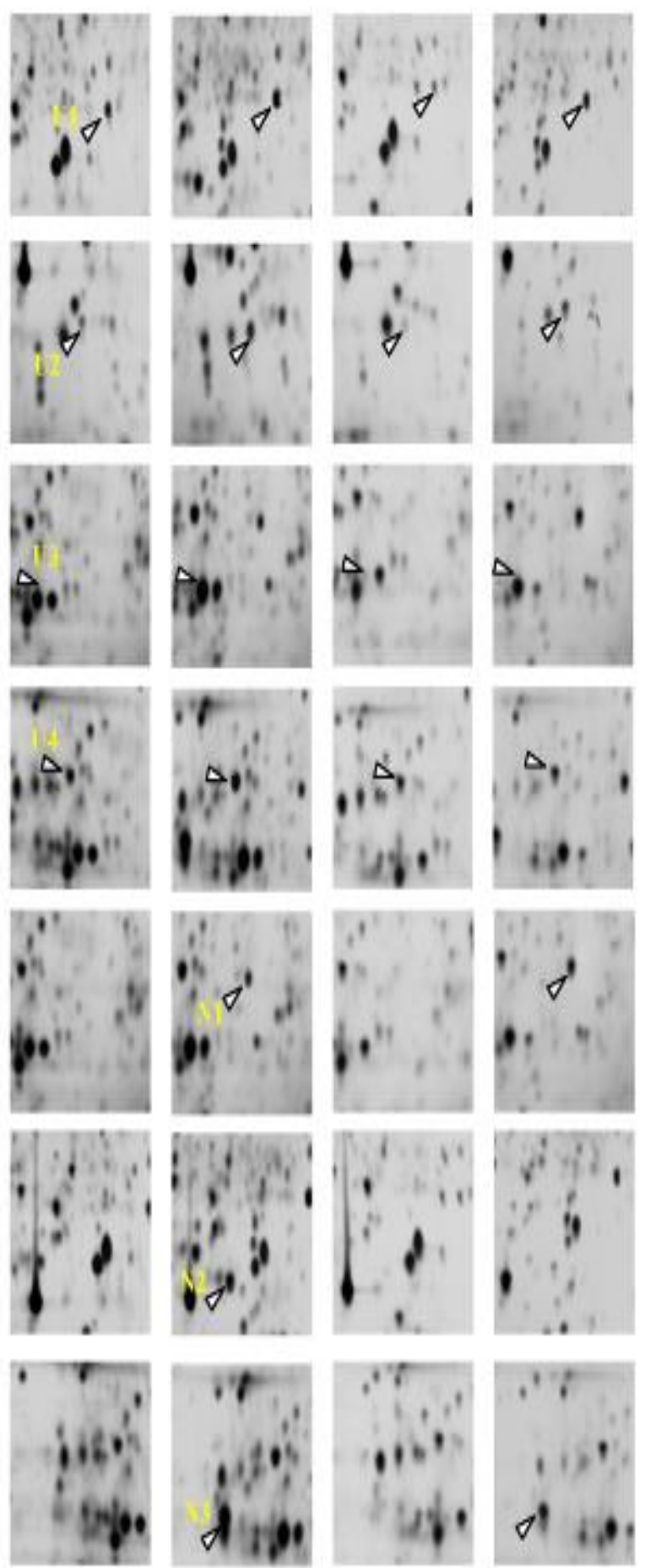
Fig.5 Hypothetical regulatory network of compatible interaction between $P$. sorghi and maize

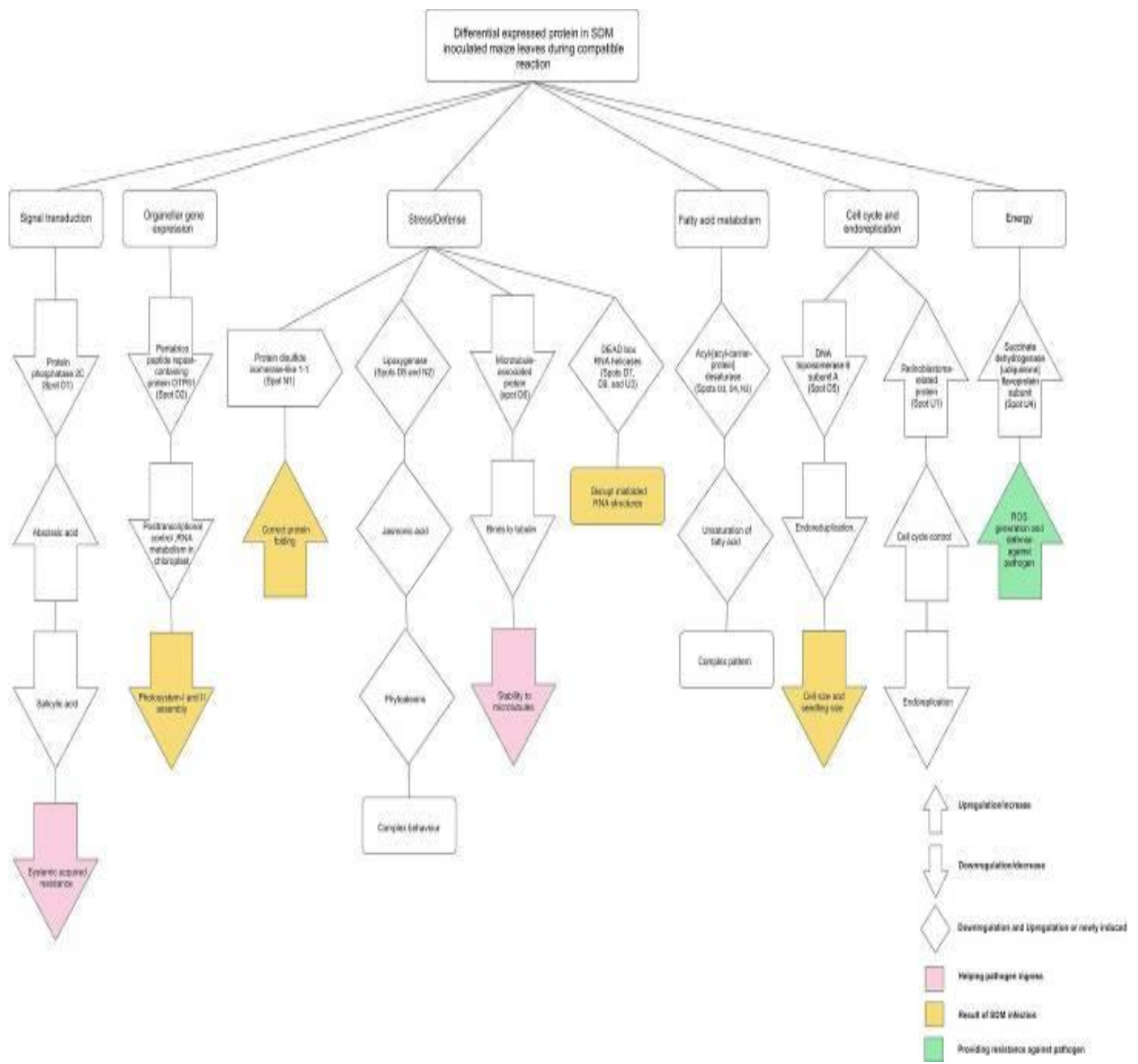

Table.1 Estimation of chlorophyll content and leaf width in control and inoculated samples of two SDM-susceptible genotypes of maize

\begin{tabular}{|l|l|l|l|l|l|}
\hline Genotype & Sample & $\begin{array}{l}\text { SPAD } \\
\text { (Mean } \mathbf{\pm} \text { SD) }\end{array}$ & $\begin{array}{l}\text { Decrease } \\
\text { over control } \\
(\boldsymbol{\%})\end{array}$ & $\begin{array}{l}\text { Leaf width } \\
(\mathbf{c m}) \\
(\mathbf{M e a n} \pm \mathbf{S D})\end{array}$ & $\begin{array}{l}\text { Decrease } \\
\text { over } \\
\text { control }(\boldsymbol{\%})\end{array}$ \\
\hline UMI79 & Control & $31.64 \pm 1.37$ & - & $4.86 \pm 0.61$ & - \\
\hline CM500 & Inoculated & $14.68 \pm 2.22$ & 53.60 & $3.70 \pm 0.57$ & 23.87 \\
\hline & Control & $33.20 \pm 1.02$ & - & $4.94 \pm 0.34$ & - \\
\hline & Inoculated & $12.80 \pm 1.31$ & 61.45 & $3.42 \pm 0.38$ & 30.77 \\
\hline
\end{tabular}

*Mean of five replications 
Table.2 Differentially expressed proteins in SDM-inoculated leaves of two maize genotypes identified by 2-DE/MALDI-TOF/MS analysis. D - Downregulated, U - Upregulated, N - Newly induced proteins

\begin{tabular}{|c|c|c|c|c|c|c|c|c|}
\hline \multirow{2}{*}{$\begin{array}{l}\text { Spot } \\
\text { ID }\end{array}$} & \multicolumn{2}{|c|}{ Abundance ratio } & \multirow{2}{*}{$\begin{array}{c}\text { Protein } \\
\text { accession no. }\end{array}$} & \multirow[t]{2}{*}{ Protein Name } & \multirow{2}{*}{$\begin{array}{l}\text { MASCOT } \\
\text { score }\end{array}$} & \multirow{2}{*}{$\begin{array}{l}\text { Sequence } \\
\text { coverage } \\
(\%)\end{array}$} & \multicolumn{2}{|c|}{$\mathrm{Mr} / \mathrm{pI}$} \\
\hline & UMI79 & CM500 & & & & & Theoretical & Experimental \\
\hline \multicolumn{9}{|c|}{ Signal transduction } \\
\hline D1 & $\begin{array}{l}0.28 \pm \\
0.06\end{array}$ & $\begin{array}{l}0.11 \pm \\
0.03\end{array}$ & P2C77_ORYSJ & $\begin{array}{l}\text { Probable protein } \\
\text { phosphatase } 2 \mathrm{C} 77\end{array}$ & 49 & 27 & $44.21 / 6.99$ & $46 / 5.82$ \\
\hline \multicolumn{9}{|c|}{ Gene expression } \\
\hline D2 & $\begin{array}{l}0.57 \pm \\
0.09\end{array}$ & $\begin{array}{l}0.22 \pm \\
0.03\end{array}$ & OTP51_ORYSJ & $\begin{array}{l}\text { Pentatricopeptide } \\
\text { repeat-containing } \\
\text { protein OTP51 }\end{array}$ & 55 & 21 & $89.94 / 6.04$ & $26 / 6.5$ \\
\hline \multicolumn{9}{|c|}{ Stress/defense } \\
\hline D7 & $\begin{array}{l}0.46 \pm \\
0.11\end{array}$ & $\begin{array}{l}0.49 \pm \\
0.11\end{array}$ & RH50_ORYSJ & $\begin{array}{l}\text { DEAD-box ATP- } \\
\text { dependent RNA } \\
\text { helicase } 50\end{array}$ & 59 & 58 & $71.44 / 9.25$ & $15 / 4.84$ \\
\hline D9 & $\begin{array}{l}0.72 \pm \\
0.03\end{array}$ & $\begin{array}{l}0.16 \pm \\
0.04\end{array}$ & RH52B_ORYSJ & $\begin{array}{l}\text { DEAD-box ATP- } \\
\text { dependent RNA } \\
\text { helicase 52B }\end{array}$ & 61 & 37 & $67.30 / 8.29$ & $53 / 6.59$ \\
\hline $\mathrm{U} 3$ & $\begin{array}{l}2.11 \pm \\
0.73\end{array}$ & $\begin{array}{l}7.66 \pm \\
2.01\end{array}$ & RH16_ORYSJ & $\begin{array}{l}\text { DEAD-box ATP- } \\
\text { dependent RNA } \\
\text { helicase } 16\end{array}$ & 56 & 67 & $74.74 / 8.61$ & $15 / 4.9$ \\
\hline D6 & $\begin{array}{l}0.59 \pm \\
0.22\end{array}$ & $\begin{array}{l}0.62 \pm \\
0.04\end{array}$ & MP702_ORYSJ & $\begin{array}{l}\text { Microtubule- } \\
\text { associated protein } 70 \text { - } \\
2\end{array}$ & 57 & 65 & $66.473 / 8.4$ & $19 / 6.37$ \\
\hline D8 & $\begin{array}{l}0.54 \pm \\
0.04\end{array}$ & $\begin{array}{l}0.40 \pm \\
0.09\end{array}$ & LOXC1_ORYSJ & Lipoxygenase 72 & 50 & 29 & $103.15 / 5.91$ & $45 / 5.33$ \\
\hline $\mathrm{N} 2$ & + & - & LOX4_ORYSJ & $\begin{array}{l}\text { Probable linoleate } \\
\text { 9S-lipoxygenase } 4\end{array}$ & 56 & 46 & $98.69 / 6.82$ & $25 / 6.33$ \\
\hline N1 & + & + & PDI11_ORYSJ & $\begin{array}{l}\text { Protein disulfide } \\
\text { isomerase-like 1-1 }\end{array}$ & 67 & 76 & $57.04 / 5.01$ & $21 / 5.21$ \\
\hline \multicolumn{9}{|c|}{ Fatty acid metabolism } \\
\hline D3 & $\begin{array}{l}0.35 \pm \\
0.10\end{array}$ & $\begin{array}{l}0.54 \pm \\
0.14\end{array}$ & STAD4_ORYSJ & $\begin{array}{l}\text { Acyl-[acyl-carrier- } \\
\text { protein] desaturase } 4\end{array}$ & 57 & 44 & $45.679 / 7.77$ & $23 / 5.62$ \\
\hline D4 & $\begin{array}{l}0.33 \pm \\
0.10\end{array}$ & $\begin{array}{l}0.62 \pm \\
0.05\end{array}$ & STAD6_ORYSI & $\begin{array}{l}\text { Acyl-[acyl-carrier- } \\
\text { protein] desaturase } 6\end{array}$ & 65 & 43 & $47.049 / 7.16$ & $22 / 5.64$ \\
\hline N3 & + & + & STAD6_ORYSJ & $\begin{array}{l}\text { Acyl-[acyl-carrier- } \\
\text { protein] desaturase } 6\end{array}$ & 85 & 61 & $46.52 / 7.65$ & $18 / 4.56$ \\
\hline \multicolumn{9}{|c|}{ Cell cycle/Endoreplication } \\
\hline U1 & $\begin{array}{l}2.39 \pm \\
0.23\end{array}$ & $\begin{array}{l}4.21 \pm \\
0.10\end{array}$ & RBR1_ORYSI & $\begin{array}{l}\text { Retinoblastoma- } \\
\text { related protein }\end{array}$ & 49 & 47 & $112.69 / 8.84$ & $31 / 6.79$ \\
\hline D5 & $\begin{array}{l}0.28 \pm \\
0.04\end{array}$ & $\begin{array}{l}0.11 \pm \\
0.02\end{array}$ & TOP6A_ORYSI & $\begin{array}{l}\text { DNA topoisomerase } \\
6 \text { subunit A }\end{array}$ & 48 & 45 & $48.61 / 9.36$ & $19 / 5.88$ \\
\hline \multicolumn{9}{|c|}{ Energy } \\
\hline U4 & $\begin{array}{l}2.07 \pm \\
0.09\end{array}$ & $\begin{array}{l}1.19 \pm \\
0.13\end{array}$ & DHSA_ORYSJ & $\begin{array}{l}\text { Succinate } \\
\text { dehydrogenase } \\
\text { [ubiquinone] } \\
\text { flavoprotein subunit }\end{array}$ & 54 & 20 & $69.49 / 6.61$ & $20 / 4.86$ \\
\hline \multicolumn{9}{|c|}{ Not significant } \\
\hline D10 & $\begin{array}{l}0.77 \pm \\
0.05\end{array}$ & $\begin{array}{l}0.83 \pm \\
0.10\end{array}$ & - & Not significant & - & - & - & $51 / 6.47$ \\
\hline $\mathrm{U} 2$ & $\begin{array}{l}3.18 \pm \\
0.05\end{array}$ & $\begin{array}{l}3.85 \pm \\
0.07\end{array}$ & - & Not significant & - & - & - & $20 / 6.47$ \\
\hline
\end{tabular}


Microtubule-associated protein binds to tubulin molecules and provides stability to microtubules. The actin microfilaments are consistently observed to target the infection site in both compatible and incompatible interaction, while microtubule response to pathogen attack was found to be variable in different plant-microbe interactions (Takemoto and Hardham, 2004). In the present study, the microtubule-associated protein 70-2 (spot D6) was found to be downregulated, which might induce instability in the microtubule and thus might have helped pathogen ingress.

Plant lipoxygenase may be involved in a number of diverse aspects of plant physiology including growth and development, pest resistance and senescence or responses to wounding. It catalyzes hydroperoxidation by introducing molecular oxygen exclusively into the C-9 and C-13 position of linoleic and linolenic acids in the octodecanoic pathway through which jasmonic acid is synthesized (De Domenico et al., 2007). In this study, probable linoleate 9S-lipoxygenase 4, a newly expressed protein (spot N2), was exclusively found in the UMI79 inoculated samples in which disease susceptibility was found to be lower than in CM500. Spot D8 (lipoxygenase 7) was observed only in the UMI79 gels and it was downregulated after infection. These differences may be the reason for differential susceptibility or resistance reaction.

Upregulation of lipoxygenases was observed in the rice black-streaked dwarf virus infection to maize. It was suggested that the increase in lipoxygenase content may result in phytoalexins and other cytotoxic products, which could improve plant resistance against pathogens (Royo et al., 1996). The decrease/downregulation of LOX due to colonization of the pathogen Sclerospora graminicola in pearl millet during compatible reaction was observed (Babitha et al., 2006).
During stress conditions, protein damage occurs because of an imbalance in cellular homeostasis. Probable protein disulphide isomerase (spot N1), a newly expressed protein after infection, facilitates correct disulphide cross-linking between and within the damaged polypeptide by rapid reshuffling of disulfide bonds until the correct set is achieved, thereby stabilizing tertiary and quaternary structure conformation, which might have been distorted because of an oxidative environment during compatible plant - pathogen interaction. Nwugo et al., (2013) reported that this protein is upregulated 1.52 times in lemon plants in response to Las infection.

\section{Fatty acid metabolism}

Fatty acids and their derivatives play important roles in plant defense responses. Acyl-[acyl-carrier-protein] desaturase is a protein found to be involved in fatty acid metabolism. It converts stearoyl-ACP to oleoyl-ACP by introducing a cis double bond.

It was represented by more than one spot with slightly different $\mathrm{Mr}$ and $\mathrm{pI}$ values, suggesting that these changes in the proteome may be attributed to post-transcriptional modification (PTM) (small shift in the pI) or degradation products (i.e., significant differences between theoretical and experimental $\mathrm{Mr}$ values).

For example, the downregulated spots D4, and the newly induced spot N3 were identified as being different forms of acyl[acyl-carrier-protein] desaturase 6, each with slight differences in $\mathrm{pI}$ and $\mathrm{Mr}$ values and could probably reflect some PTMs occurring in vivo or be the consequence of artifactual modifications such as deamidation in the proteins during sample preparation and proteolytic processing or the existence of different genes encoding the same protein (Jorge et al., 2005). 


\section{Cell cycle/endoreplication}

Tumor suppressor protein, a retinoblastoma protein, is a negative regulator of cell cycles, a well-studied example of cell cycle regulator in mammals. It acts during the G1 to S phase transition checkpoint. In a dephosphorylated state, RB binds to E2F transcription factor, thereby suppressing it, which in turn terminates transcription of the genes encoding enzymes required for DNA replication machinery during the $S$ phase. Retinoblastoma-related protein (RBR) (Spot U1) is a plant homologue of the retinoblastoma protein, found to be upregulated in both genotypes after infection. The extend of upregulation was much higher in the CM500 than UMI79 (variance=1.65; supplementary table S4) Besides cell cycle control, its role in histone deacytalase chromosome modelling increases in heterochromatisation, thereby suppressing the transcription as was observed in previous reports.

RBR interacts with the geminiviridae replication-associated proteins and favors viral DNA replication (Ascencio-Ibáñez et al., 2008; Desvoyes et al., 2013). Similarly, RBR may play a role in pathogen proliferation; however, further studies are needed to confirm the actual mechanism. Endoreduplication (duplication of a genome without further mitotic division) is observed in many compatible biotrophic plant-pathogen interaction studies to mitigate metabolite demand of successful invaded and established pathogens (Chandran et al., 2010; Chandran et al., 2013; de Almeida Engler and Gheysen 2013). RBR plays a key role in regulating endoreduplication. Suppression of endogenous NbRBR1 in tobacco by virusinduced gene silencing (VIGS) was found to increase endoreduplication in tobacco leaf (Park et al., 2005), whereas studies on RBR overexpression in its own domain revealed suppression of both endoreplication and cell proliferation (Magyar et al., 2012). The phosphorylated, dephosphorylated or hyperphosphorylated state of RBR also determines its activity, for instance, hyperphosphorylation of RBR was found to increase polyploidization of maize endosperm. Thus, the complex nature and diverse function of RBR needs further study to gain an insight into the maize - $P$. sorghi pathogen interaction.

DNA topoisomerase 6 subunit $A$ is a component of the DNA topoisomerase VI, which is involved in chromatin organization and progression of endoreduplication cycles. As endoreduplication increases, cell size increases, whereas mutants with a loss of function of DNA topoisomerase VI subunit A leads to dwarf seedlings, reduced root hairs, and small/under-branched trichomes (Hartung et al., 2002; Sugimoto-Shirasu et al., 2002; Yin et al., 2002). Downregulation extend is high in the CM500 $(0.11 \pm 0.02)$ than UMI79 $(\mathrm{AR}=0.28 \pm 0.04)$. Similarly, the CM500 had high decrease in the leaf width in infected samples over control (30\%) than the UMI79 $(23 \%)$.

\section{Energy}

Excess food demand by an established pathogen in a susceptible host is mitigated by higher respiration and oxidative phosphorylation. The succinate dehydrogenase [ubiquinone]-flavoprotein (FP) subunit of succinate dehydrogenase $(\mathrm{SDH})$ was found to be upregulated in the present study (spot U4). SDH is involved in complex II of the mitochondrial electron transport chain and is responsible for transferring electrons from succinate to ubiquinone (coenzyme Q). Mitochondria are both a source of ATP and a site for reactive oxygen species (ROS) production. It has been established that SDH of the electron transport 
chain contributes to localized mitochondrial ROS and hence regulates plant stress and defense responses (Gleason et al., 2011).

Our study has provided the first insights into the maize - $P$. sorghi compatible interaction, revealing that the biotrophic pathogen $P$. sorghi induced downregulation of PP2C and thereby suppressed systemic acquired resistance. $P$. sorghi infection directly or indirectly affects organeller gene expression, and photosystem I and II and modulate host cell cycle, which was corroborated by the phenotypic symptoms such as chlorosis and leaf narrowing. Although we used both susceptible hosts in this study, it was evident from proteomics studies that the host tries to sustain itself during infection through some mechanism such as RNA chaperon and protein disulphide isomerase to withstand an oxidative environment during compatible plant - pathogen interaction. Overall, this study gives cues to understand the changes in protein abundance levels that occur upon infection by SDM in maize. It also serves as a basic prelude to comprehend maize-SDM interaction, which needs to be validated through functional genomics approaches.

\section{Competing interests}

We declare that there are no conflicts of interests.

\section{Author contributions}

Conceived and designed the experiments: NS, KNG, JR; performed the 2D experiment: MR, RVR, KPJ; MALDI-TOF/MS analysis: NA, GSK; downy mildew inoculation and disease establishment: PMT, KS, VP.

\section{Acknowledgments}

The financial support from the Department of Biotechnology, Government of India, under for scheme no. BT/PR/108910/ GBD/27/111/2008 provided to NS is kindly acknowledged. We thank the UGC for providing a fellowship to KPJ to participate in the doctoral research program.

\section{References}

Ajala S, Kling J, Kim S and Obajimi A (2003) Improvement of maize populations for resistance to downy mildew. Plant breeding 122(4):328-333

Amey R, Schleicher T, Slinn J, Lewis M, Macdonald $H$, Neill $S$ and SpencerPhillips PT (2008) Proteomic analysis of a compatible interaction between Pisum sativum (pea) and the downy mildew pathogen Peronospora viciae. European Journal of Plant Pathology 122(1):41-55

Ascencio-Ibáñez JT, Sozzani R, Lee T-J, Chu T-M, Wolfinger RD, Cella R and HanleyBowdoin L (2008) Global analysis of Arabidopsis gene expression uncovers a complex array of changes impacting pathogen response and cell cycle during geminivirus infection. Plant Physiology 148(1):436-454

Asselbergh B, Curvers K, França SC, Audenaert K, Vuylsteke M, Van Breusegem F and Höfte M (2007) Resistance to Botrytis cinerea in sitiens, an abscisic acid-deficient tomato mutant, involves timely production of hydrogen peroxide and cell wall modifications in the epidermis. Plant Physiology 144(4):1863-1877

Babitha M, Prakash H and Shetty HS (2006) Induction of lipoxygenase in downy mildew resistant seedlings of pearl millet in response to inoculation with Sclerospora graminicola. International Journal of Agriculture and Biology 8(4):560-564

Blum H, Beier $\mathrm{H}$ and Gross HJ (1987) Improved silver staining of plant proteins, RNA and DNA in polyacrylamide gels. Electrophoresis 8(2):93-99 
Bradford MM (1976) A rapid and sensitive method for the quantitation of microgram quantities of protein utilizing the principle of protein-dye binding. Analytical biochemistry 72(1): 248-254

Butt YK-C and Lo SC-L (2007) Proteomic Studies on Plant-Pathogen Interaction in Compatible and Incompatible Systems. Current Proteomics 4(3): 141-156

Cayalvizhi B, Nagarajan P, Raveeendran M, Rabindran R, Selvam NJ, Bapu JK and Senthil N (2015) Unraveling the responses of mungbean (Vigna radiata) to mungbean yellow mosaic virus through 2D-protein expression. Physiological and Molecular Plant Pathology 90:65-77

Chandran D, Inada N, Hather G, Kleindt CK and Wildermuth MC (2010) Laser microdissection of Arabidopsis cells at the powdery mildew infection site reveals site-specific processes and regulators. Proceedings of the National Academy of Sciences 107(1): 460-465

Chandran D, Rickert J, Cherk C, Dotson BR and Wildermuth MC (2013) Host cell ploidy underlying the fungal feeding site is a determinant of powdery mildew growth and reproduction. Molecular Plant-Microbe Interactions 26(5):537-545

Cottrell JS and London U (1999) Probabilitybased protein identification by searching sequence databases using mass spectrometry data. Electrophoresis 20(18): 3551-3567

Craig J, Bockholt A, Frederiksen R and Zuber M (1977) Reaction of important corn inbred lines to Sclerospora sorghi. Plant Disease Reporter 61(7): 563-564

De Almeida Engler J and Gheysen G (2013) Nematode-induced endoreduplication in plant host cells: why and how? Molecular Plant-Microbe Interactions 26(1):17-24

De Domenico S, Tsesmetzis N, Di Sansebastiano GP, Hughes RK, Casey R and Santino A (2007) Subcellular localisation of Medicago truncatula 9/13hydroperoxide lyase reveals a new localisation pattern and activation mechanism for CYP74C enzymes. BMC plant biology 7(1):58

Desvoyes B, de Mendoza A, Ruiz-Trillo I and Gutierrez C (2013) Novel roles of plant RETINOBLASTOMA-RELATED

(RBR) protein in cell proliferation and asymmetric cell division. Journal of experimental botany: ert411

Gerpacio RV and Pingali PL (2007) Tropical and subtropical maize in Asia: production systems, constraints, and research priorities. Cimmyt

Gleason C, Huang S, Thatcher LF, Foley RC, Anderson CR, Carroll AJ, Millar AH and Singh KB (2011) Mitochondrial complex II has a key role in mitochondrial-derived reactive oxygen species influence on plant stress gene regulation and defense. Proceedings of the National Academy of Sciences 108(26): 10768-10773

Hartung F, Angelis KJ, Meister A, Schubert I, Melzer M and Puchta H (2002) An archaebacterial topoisomerase homolog not present in other eukaryotes is indispensable for cell proliferation of plants. Current Biology 12(20): 17871791

Hoisington D and Melchinger A (2004) From theory to practice: Marker-assisted selection in maize Molecular Marker Systems in Plant Breeding and Crop Improvement. Springer, p 335-352

Hok S, Attard A and Keller H (2010) Getting the most from the host: how pathogens force plants to cooperate in disease. Molecular plant-microbe interactions 23(10): 1253-1259

Hu X, Zhang H, Li G, Yang Y, Zheng Z and Song F (2009) Ectopic expression of a rice protein phosphatase $2 \mathrm{C}$ gene OsBIPP2C2 in tobacco improves disease resistance. Plant cell reports 28(6): 985995

Isakeit $\mathrm{T}$, Odvody $\mathrm{G}$, Jahn $\mathrm{R}$ and Deconini $\mathrm{L}$ (2003) Peronosclerospora sorghi resistant to metalaxyl treatment of sorghum seed in Texas. Phytopathology 93: S39 
Jagadish S, Muthurajan R, Oane R, Wheeler TR, Heuer S, Bennett J and Craufurd PQ (2010) Physiological and proteomic approaches to address heat tolerance during anthesis in rice (Oryza sativa L.). Journal of Experimental Botany 61(1): 143-156

Jorge I, Navarro RM, Lenz C, Ariza D, Porras C and Jorrín J (2005) The Holm Oak leaf proteome: Analytical and biological variability in the protein expression level assessed by 2- DE and protein identification tandem mass spectrometry de novo sequencing and sequence similarity searching. Proteomics 5(1): 222-234

Kav NN, Srivastava S, Yajima W and Sharma N (2007) Application of proteomics to investigate plant-microbe interactions. Current Proteomics 4(1): 28-43

Kundu S, Chakraborty D, Kundu A and Pal A (2013) Proteomics approach combined with biochemical attributes to elucidate compatible and incompatible plant-virus interactions between Vigna mungo and Mungbean Yellow Mosaic India Virus. Proteome science 11(1): 15

Li K, Xu C and Zhang J (2011) Proteome profile of maize (Zea mays L.) leaf tissue at the flowering stage after long-term adjustment to rice black-streaked dwarf virus infection. Gene 485(2): 106-113

Longevialle D, Falcon A, Hendrickson L, Taylor NL, Delannoy E, Lurin C, Badger M, Millar AH and Small I (2008) The pentatricopeptide repeat gene OTP51 with two LAGLIDADG motifs is required for the cis- splicing of plastid ycf3 intron 2 in Arabidopsis thaliana. The Plant Journal 56(1): 157-168

Magyar Z, Horváth B, Khan S, Mohammed B, Henriques R, De Veylder L, Bakó L, Scheres B and Bögre L (2012) Arabidopsis E2FA stimulates proliferation and endocycle separately through RBR- bound and RBR- free complexes. The EMBO journal 31(6): 1480-1493
Milli A, Cecconi D, Bortesi L, Persi A, Rinalducci S, Zamboni A, Zoccatelli G, Lovato A, Zolla L and Polverari A (2012) Proteomic analysis of the compatible interaction between Vitis vinifera and Plasmopara viticola. Journal of proteomics 75(4): 1284-1302

Mohr PG and Cahill DM (2007) Suppression by ABA of salicylic acid and lignin accumulation and the expression of multiple genes, in Arabidopsis infected with Pseudomonas syringae pv. tomato. Functional and integrative genomics 7(3): 181-191

Nallathambi $P, \quad$ Sundaram $\mathrm{KM}$ and Arumugachamy S (2010) Inheritance of Resistance to Sorghum Downy mildew (Peronosclerospera sorghi) in Maize (Zea mays L.). International Journal of Agriculture, Environment and Biotechnology 3(3): 285-293

Park JA, Ahn JW, Kim YK, Kim SJ, Kim JK, Kim WT and Pai HS (2005) Retinoblastoma protein regulates cell proliferation, differentiation, and endoreduplication in plants. The Plant Journal 42(2): 153-163

Premalatha N, Sundaram KM and Arumugachamy S (2012) Screening and source of resistance to downy mildew (Peronosclerospora sorghi) in maize (Zea mays L.). Electronic Journal of Plant Breeding 3(2): 788-793

Royo J, Vancanneyt G, Pérez AG, Sanz C, Störmann K, Rosahl S and SánchezSerrano JJ (1996) Characterization of three potato lipoxygenases with distinct enzymatic activities and different organspecific and wound-regulated expression patterns. Journal of Biological Chemistry 271(35): 21012-21019

Safeeulla K (1976) Biology and control of the downy mildews of pearl millet, sorghum and finger millet. Biology and control of the downy mildews of pearl millet, sorghum and finger millet.

Schmitz-Linneweber C and Small I (2008) Pentatricopeptide repeat proteins: a socket 
set for organelle gene expression. Trends in plant science 13(12): 663-670

Schweighofer A, Hirt H and Meskiene I (2004)

Plant PP2C phosphatases: emerging functions in stress signaling. Trends in plant science 9(5): 236-243

Sheen J (1998) Mutational analysis of protein phosphatase $2 \mathrm{C}$ involved in abscisic acid signal transduction in higher plants. Proceedings of the National Academy of Sciences 95(3): 975-980

Shevchenko A, Wilm M, Vorm O and Mann M (1996) Mass spectrometric sequencing of proteins from silver-stained polyacrylamide gels. Analytical chemistry 68(5): 850-858

Singburaudom N and Renfro B (1982) Heritability of resistance in maize to sorghum downy mildew $(<\quad \mathrm{i}\rangle$ Peronosclerospora sorghi $</ \mathrm{i}>$ (Weston and Uppal) CG Shaw). Crop Protection 1(3): 323-332

Sugimoto-Shirasu K, Stacey NJ, Corsar J, Roberts K and McCann MC (2002) DNA topoisomerase $\mathrm{VI}$ is essential for endoreduplication in Arabidopsis. Current Biology 12(20): 1782-1786

Takemoto D and Hardham AR (2004) The cytoskeleton as a regulator and target of biotic interactions in plants. Plant Physiology 136(4): 3864-3876

Valcu C-M, Junqueira M, Shevchenko A and Schlink K (2009) Comparative proteomic analysis of responses to pathogen infection and wounding in Fagus sylvatica. Journal of proteome research 8(8): 4077-4091

Wasteneys GO and Galway ME (2003) Remodeling the cytoskeleton for growth and form: an overview with some new views. Annual Review of Plant Biology 54(1): 691-722

Williams R (1984) Downy mildews of tropical cereals. Advances in plant pathology 2: 1103

Xing T, Ouellet T and Miki BL (2002) Towards genomic and proteomic studies of protein phosphorylation in plant-pathogen interactions. Trends in plant science 7(5): 224-230

Yasuda M, Ishikawa A, Jikumaru Y, Seki M, Umezawa T, Asami T, MaruyamaNakashita A, Kudo T, Shinozaki K and Yoshida S (2008) Antagonistic interaction between systemic acquired resistance and the abscisic acid-mediated abiotic stress response in Arabidopsis. The Plant Cell 20(6): 1678-1692

Yen TTO, Prasanna B, Setty T and Rathore R (2004) Genetic variability for resistance to sorghum downy mildew (Peronosclerospora sorghi) and Rajasthan downy mildew $(P$. heteropogoni) in the tropical/sub-tropical Asian maize germplasm. Euphytica 138(1): 23-31

Yin Y, Cheong H, Friedrichsen D, Zhao Y, Hu J, Mora-Garcia S and Chory J (2002) A crucial role for the putative Arabidopsis topoisomerase VI in plant growth and development. Proceedings of the National Academy of Sciences 99(15): 1019110196

Zhou W, Eudes F and Laroche A (2006) Identification of differentially regulated proteins in response to a compatible interaction between the pathogen Fusarium graminearum and its host, Triticum aestivum. Proteomics 6(16): 4599-4609

\section{How to cite this article:}

Jadhav, K.P., R. Veera Ranjani, N. Senthil, N. Arulkumar, P.M. Tamilarasi, K. Sumathi, K.N. Ganesan, V. Paranidharan, M. Raveendran, Gon Sup Kim and Ramalingam, J. 2018. Proteomic Analysis of a Compatible Interaction between Sorghum Downy Mildew Pathogen (Peronosclerospora sorghi) and Maize (Zea mays L.). Int.J.Curr.Microbiol.App.Sci. 7(11): 653670. doi: https://doi.org/10.20546/ijcmas.2018.711.079 